\title{
PENGARUH TEKNIK RELAKSASI OTOT PROGRESIF TERHADAP PENURUNAN KADAR GULA DARAH PADA PASIEN DIABETES MELLITUS TIPE 2 DI RUMAH SAKIT GRANDMED LUBUK PAKAM
}

\author{
Tati Murni Karokaro', Muhammad Riduan² \\ Institut Kesehatan Medistra Lubuk Pakam \\ Fakultas Keperawatan dan Fisioterapi Program Studi Ilmu Keperawatan \\ Jl. Sudirman No 38 Lubuk Pakam, Kab. Deli Serdang SUMUT \\ tatikarokaro612sp@gmail.com
}

DOI: https://doi.org/10.35451/jkf.v1i2.169

\begin{abstract}
The prevalence of diabetes occuring in 2015 is 9,3\% and is expected to increase annualy. Type 2 diabetes mellitus occurs because insulin resistance, which glucose fails to enter the cell, usually occurs in the age above 30 years. One of the modalitas therapy that can be done is progressive muscle relaxation. The purpose of the study was to the identify the effect of progressive muscle relaxation therapy on the decrease in blood sugar levels in patients with type 2 diabetes mellitus at hospital GRANDMED Lubuk Pakam. This research method used pre-experimental design with one group pretest-posttest. A sample size of 10 respondents selected by sampling technique of non-probability sampling type consecutive sampling. The result of paired hypothesis test of $t$-test sample at significance level $95 \%$ obtained $p$ Value $<a$, that is 0,001 indicates that there is influence of progressive muscle relaxation therapy to decrease blood glucose level in type 2 diabetes mellitus patient. Conclusion obtained there is significant difference between blood glucose levels before and after progressive muscle relaxation therapy. It is sugessted that health care institutions need to implement new policies related to the application of progressive muscle relaxation therapy.
\end{abstract}

Keywords: type 2 diabetes mellitus, progressive muscle relaxation therapy, blood sugar levels.

\section{Pendahuluan}

Relaksasi otot progresif merupakan salah satu tindakan yang dapat menurunkan kadar glukosa didalam darah terkhusus pada pasien DM, hal ini dapat terjadi dikarenakan adanya proses penekanan pada saat mengeluarkan hormon-hormon yang dapat memicu terjadinya meningkatkan kadar glukosa didalam darah, yaitu epinefrin, kortisol, glukagon, adrenocorticotropic hormone (ACHT), kortikosteroid, dan tiroid. Sistem Syaraf simpatis akan sangat berperan ketika seseorang dalam kondisi yang rileks dan tenang, pada saat yang relaks dan tenang sistem saraf simpatis akan merangsang hipotalamus untuk menurunkan pengeluaran Corticotropin-Realising 
Hormon ( $\mathrm{CRH})$. Penurunan pengeluaran dari CRH juga akan dapat mempenga ruhi adenohipofisis untuk mengurangi pengeluaran adrenocorticotropic hormone $(\mathrm{ACHT})$, yang dibawa melalui aliran darah ke korteks adrenal. Keadaan tersebut dapat menghambat korteks adrenal untuk melepaskan hormon kortisol. Relaksasi otot progresif dapat digunakan pada semua orang dalam berbagai situasi dan kondisi terkhusus pada pasien dengan diabetes mellitus (Guyton \& Hall, 2008, dan Setyohadi \& Kushariyadi, 2011).

\section{Internasional Diabetes Federation} (IDF) tahun 2015 dari 177 juta jiwa di dunia yang menderita penyakit DM tipe 2 dan 25 tahun yang akan datang meningkat menjadi 300 juta jiwa, prevalensi diabetes tipe 2 tahun 2016 pada penduduk Amerika Serikat yang diatas berusia 65 tahun atau lebih yaitu sekitar 10,9 juta jiwa (26,9\%), sedangkan di Indonesia jumlah pasien diabetes mellitus tipe 2 mengalami kenaikan, dari 8,4\% juta jiwa pada tahun 2017 dan diperkirakan naik menjadi $21,3 \%$ juta jiwa pada tahun 2022. Jumlah penderita pasien DM di Indonesia sangat tinggi sehingga beradad pada peringkat $4 \mathrm{di}$ dunia berada di peringkat ke keempat dunia setelah negara negara lainnya seperti Amerika Serikat, India, dan China (Wild, 2018 dan Sudoyo, 2006).

Di Sumatera Utara khususnya RSUP H.Adam Malik Medan berdasarkan pengelompokan penyakit dan berbagai tingkatan seperti umur, jumlah kasus diabetes melitus menempati nomor dua setelah penyakit neoplasma yang bersifat keganasan, sedangkan data kematian pasien berdasarkan jenis penyakit DM berada di peringkat ke 16 dibandingkan dengan penyakit lainnya. (Dinkes SUMUT, 2009).

Hasil dari studi pendahuluan yang dilakukan pada tanggal 04 November 2018 dari medical record RS.GRANDMED
Lubuk Pakam, penderita penyakit dalam yang dirawat sejak bulan Januari 2018 Desember 2018 sebanyak 20.506 orang. Diantara penderita penyakit dalam ditemukan penyakit dengan gangguan sistem endokrin "Diabetes Mellitus Tipe 2" sebanyak 568 orang dengan prevalensi $2,77 \%$ terdiri dari pria sebanyak 328 $(57,8 \%)$ orang dan wanita $240(42,2 \%)$ orang, penanganan yang dilakukan untuk menurunkan kadar gula darah pada pasien Diabetes Mellitus Tipe 2, RS. GRANDMED Lubuk Pakam sendiri masih bergantung dengan terapi farmakologi, seperti pemberian injeksi Insulin sebagai pengontrol kadar gula darah pasien Diabetes Mellitus Tipe 2 dan berbagai jenis obat oral seperti Metformin. Tujuan pada penelitian ini adalah untuk melihat apakah ada pengaruh teknik relaksasi otot progresif terhadap penurunan kadar gula darah pada pasien DM tipe 2 di RS.GranMed Lubuk Pakam.

\section{METODE}

Metode yang dilakukan pada penelitian ini adalah dengan cara secara Quasi experiment, yang bertujuan untuk mengetahui pengaruh teknik relaksasi otot progresif terhadap penurunan kadar gula arah pada pasien diabetes mellitus tipe 2 di RS.GRANDMED Lubuk Pakam. Penelitian ini menggunakan sampel pasien DM tipe 2.Penelitian ini dilakukan selama 2 minggu. Pada penelitian ini teknik pengambilan sampel yang digunakan nonprobability sampling yaitu purposive sampling. 


\section{HASIL}

\section{Hasil Tabulasi Univariat}

Tabel 4.1

Hasil Analisis Kadar Gula Darah Sebelum Dilakukan Teknik Relaksasi Otot Progresif Di Rumah Sakit GRANDMED Lubuk Pakam Tahun 2019

\begin{tabular}{|l|c|c|c|c|}
\hline $\begin{array}{c}\text { Kadar } \\
\text { gula } \\
\text { darah }\end{array}$ & Mean & $\mathrm{N}$ & $\begin{array}{c}\text { Std. } \\
\text { Deviat } \\
\text { ion }\end{array}$ & $\begin{array}{c}\text { Std. } \\
\text { Error } \\
\text { Mean }\end{array}$ \\
\hline $\begin{array}{l}\text { Kadar } \\
\text { gula } \\
\text { darah } \\
\text { sebelum } \\
\text { dilakuka } \\
\text { n teknik } \\
\text { relaksasi } \\
\text { otot } \\
\text { progresif }\end{array}$ & $\begin{array}{c}243.9 \\
\text { not }\end{array}$ & 10 & $\begin{array}{c}11.21 \\
0\end{array}$ & 3.545 \\
\hline
\end{tabular}

Hasil yang didapat berdasarkan Tabel 4.1 sebelum dilakukan tehnik relaksasi otot progresif adalah 243,90, dengan standar deviasi (SD) 11,210 dan standar error (SE) 3, 54.

Tabel 4.2

Hasil Analisis Kadar Gula Darah Sesudah Dilakukan Teknik Relaksasi Otot Progresif Di Rumah Sakit GRANDMED Lubuk Pakam Tahun 2019

Analisis Tabel 4.2 diatas menunjukkan bahwa rata rata kadar gula darah sesudah dilakukan teknik relaksasi otot progresif sebesar 200,80, dengan standar deviasi (SD) 31,407 dan standar error (SE) 9,932.

\section{Hasil Tabulasi Bivariat}

Tabel 4.3

Hasil Analisis Kadar Gula Darah Sebelum Dan Sesudah Dilakukan Teknik Relaksasi Otot Progresif Di Rumah Sakit GRANDMED Lubuk Pakam tahun 2019

\begin{tabular}{|c|c|c|c|c|c|}
\hline $\begin{array}{c}\text { Kada } \\
r \\
\text { gula } \\
\text { dara } \\
\mathrm{h}\end{array}$ & $\mathrm{N}$ & Mean & $\begin{array}{c}\text { Standar } \\
\text { Deviasi } \\
(\mathrm{SD})\end{array}$ & $\begin{array}{c}\text { Standa } \\
\text { Erorr } \\
(\mathrm{SE})\end{array}$ & $\begin{array}{c}p \text { Val } \\
\text { ue }\end{array}$ \\
\hline $\begin{array}{c}\text { Sebe } \\
\text { lum } \\
\text { dan } \\
\text { sesu } \\
\text { dah }\end{array}$ & 10 & 43.1 & 27.795 & 8.789 & 0,00 \\
& & 00 & & & \\
\hline
\end{tabular}

Tabel 4.3 menunjukkan rata-rata kadar gula darah pada pasien diabetes mellitus tipe 2 sebelum dan sesudah dilakukan teknik relaksasi otot progresif sebesar 43,100, dengan standar deviasi (SD) 27, 795 dan standar error (SE) 8,789. Hasil uji statistik didapatkan nilai $\mathrm{p}=0,001 \leq \mathrm{a}=$ 0,05 maka dapat disimpulkan bahwa terdapat pengaruh teknik relaksasi otot progresif terhadap kadar gula darah pada pasien diabetes mellitus tipe 2 di rumah sakit GRANDMED Lubuk Pakam tahun 2019.

\section{PEMBahasan}

\section{Kadar Gula Darah Pada Pasien Diabetes Mellitus Tipe 2 Sebelum Dilakukan Teknik Relaksasi Otot Progresif Di Rumah Sakit GRANDMED Lubuk Pakam Tahun 2019.}

\begin{tabular}{|l|c|c|c|c|}
\hline $\begin{array}{l}\text { Kadar gula } \\
\text { darah }\end{array}$ & Mean & $\mathrm{N}$ & $\begin{array}{c}\text { Std. } \\
\text { Deviation }\end{array}$ & $\begin{array}{c}\text { Std. Error } \\
\text { Mean }\end{array}$ \\
\hline $\begin{array}{l}\text { Kadargula } \\
\text { darah } \\
\text { sesudah } \\
\text { dilakukan } \\
\text { teknik } \\
\text { relaksasi } \\
\text { otot } \\
\text { progresif }\end{array}$ & 200.80 & 10 & 31.407 & 9.932 \\
\hline
\end{tabular}


Kadar gula darah pada pasien diabetes sebelum dilakukan teknik relaksasi otot progresif yang hanya memakai terapi injeksi insulin yaitu responden sebanyak 10 orang, didapat hasil dengan rata-rata $244 \mathrm{mg} / \mathrm{dl}$. Hasil penelitian dapat diasumsikan bahwa pemberian terapi injeksi insulin pada pasien diabetes mellitus tipe 2 tanpa adanya pemberian teknik relaksasi otot progresif, hasilnya tidak begitu berpengaruh. Penyakit DM tipe 2 adalah penyakit kronik yang mengakibatkan kelainan metabolisme tubuh manusia dengan komplikasi secara makrovaskuler dan neurologis, sesuai dengan penelitian yang dilakukan Widianingsih bahwa dengan melakukan teknik relaksasi otot progresif pada pasien DM tipe 2 akan dapat penurunan kadar gula darah dengan cepat. Teknik relaksasi otot progresif yang diberikan kepada pasien dengan cara menarik napas dalam, (Damayanti Santi, 2015, dan Kustanti \& Widodo, 2008).

\section{Kadar Gula Darah Pada Pasien Diabetes Mellitus Tipe 2 Sesudah Dilakukan Teknik Relaksasi Otot Progresif Di Rumah Sakit GRANDMED Lubuk Pakam Tahun 2019}

Kadar gula darah pada pasien DM tipe 2 sesudah dilakukan teknik relaksasi otot progresif disertai dengan pemberian terapi injeksi unsulin yaitu sebanyak 10 orang dengan rata-rata hasil kadar gula darah sebesar $201 \mathrm{mg} / \mathrm{dl}$, hal ini dapat terjadi dikarenakan pemberian teknik relaksasi otot progresif dapat menurunkan kadar gula darah pada pasien diabetes mellitus tipe 2 secara bertahap serta dapat memelihara dan meningkatkan kesehatan yang kondusif.

Penelitian junaidi dari 30 responden terdapat 23 penelitian mengalami penurunan kadar gula darah dengan pendekatan dan sosialisasi baik secara langsung ataupun tidak langsung, namun pendekatan yang dilakukan akan mampu menurunkan kadar gula darah pasien DM tipe 2 . Tubuh manusia memberikan respon terhadap kecemasan yang dapat mengakibatkan pikiran tidak stabil dengan memberikan rangsangan ataupun stimulus pada otot diharapkan dapat menurunkan ketegangan dengan yang menggunakan latihan nafas dalam dan relaksasi pada otot tertentu ( Kustanti dan Widodo, 2008, junaidin,2018).

\section{Pengaruh Teknik Relaksasi Otot Progresif Terhadap Penurunan Kadar Gula Darah Pada Pasien Diabetes Mellitus Tipe 2 Di Rumah Sakit GrandMed Lubuk Pakam Tahun 2019}

Rerata hasil kadar gula darah pertama 243.90 pada pengukuran kedua diadapat hasil kadar gula darah 200.80, terlihat Mean antara kedua pengukuran pertama dan kedua adalah 222, 35 dengan standar deviasi (SD) 27.795. Hasil uji didapat nilai $p=0,001 \leq a=0,05$ sehingga disimpulkan terdapat pengaruh teknik relaksasi otot progresif terhadap penurunan kadar gula darah pada pasien DM tipe 2 di rumah sakit GrandMed Lubuk Pakam.

Hasil penelitian dapat diasumsikan bahwa pemberian terapi injeksi insulin pada pasien diabetes mellitus tipe 2 tanpa adanya pemberian teknik relaksasi otot progresif, namun hasil yang diperoleh kurang bermakna. Penyakit DM tipe 2 adalah salah satu penyakit kronis melibatkan kerja metabolisme karbohidrat, protein dan lemak didalam tubuh, sesuai dengan penelitian yang dilakukan Widianingsih bahwa pemberian teknik relaksasi otot progresif pada pasien DM tipe 2 dapat menurunkan kadar gula darah dengan sangat cepat. Teknik relaksasi otot progresif yang dilakukan pada pasien DM yang mengalami ketegangan pada otot-otot tertentu dengan mengkombinasikan dengan latihan nafas dalam maka diharapkan hasilnya adalah terjadinya penurunan 
ketegangan pada otot diikuti dengan penurunan kadar gula dalam darah, (Damayanti Santi, 2015, dan Kustanti \& Widodo, 2008).

Penelitian junaidi mengala mi penurunan kadar gula darah dengan pendekatan dan sosialisasi baik secara langsung ataupun tidak akan dapat menurunkan kadar gula darah pasien DM tipe 2. Berdasarkan respon tubuh manusia yang mengalami kecemasan dan gangguan pikiran akan mengakibatkan ketegangan pada otot kemudian relaksasi yang diberikan diharapkan dapat menurunkan ketegangan dengan cara latihan nafas dalam dan relaksasi otot tertentu (Kustanti dan Widodo, 2008, junaidin, 2018).

Peran perawat inap juga sangat berperan penting terhadap pemberian teknik relaksasi otot progresif untuk menurunkan kadar gula darah. Pada tatanan fungsi perawat rawat inap saat pelaksanaan teknik relaksasi otot progresif adalah tidak hanya pada fungsi pelaksanaan prosedur saja, tetapi juga menyiapkan mental pasien dan kerjasama dengan keluarga pasien, pemberian teknik relaksasi otot progresif pada pasien diabetes mellitus tipe 2 dapat menurunkan kadar gula darah pada responden yang berbeda-beda. Sehingga peneliti dapat menciptakan suasana lingkungan internal yang dapat membantu pasien mencapai kondisi kesehatan yang optimal dan kesejahteraan yang lebih tinggi.

\section{KESIMPULAN}

1. Rerata hasil kadar gula darah sebelum dilakukan teknik relaksasi otot progresif dari 10 responden pasien diabetes mellitus tipe 2 dengan hasil sebesar $244 \mathrm{mg} / \mathrm{dl}$.

2. Rerata hasil kadar gula darah sesudah dilakukan teknik relaksasi otot progresif dari 10 responden pasien diabetes mellitus tipe 2 dengan hasil sebesar $201 \mathrm{mg} / \mathrm{dl}$.

3. Ada pengaruh teknik relaksasi otot progresif terhadap penurunan kadar gula darah pada pasien diabets mellitus tipe 2. Berdasarkan hasil uji statistik dengan menggunakan uji paired t-test menunjukkan baha $p$ Value yaitu 0,001 yang berarti $p$ Value $<$ dari $a=0,05$.

\section{SARAN}

Diharapkan agar responden yang mengalami peningkatan kadar gula darah pada pasien diabets mellitus tipe 2 agar dapat menerapkan teknik relaksasi otot progresif terhadap penurunan kadar gula darah.

Bagi Rumah Sakit GrandMed Lubuk Pakam agar dapat menerapkan Teknik relaksasi otot progresif dimana Teknik relaksasi otot progresif merupakan salah satu terapi modalitas keperawatan yang mudah dan dapat dipilih untuk diterapkan pada tindakan keperawatan dengan pasien diabetes mellitus tipe 2 yang mengalami kenaikan kadar gula darah

Bagi Institut Kesehatan Medistra Lubuk Pakam agar dapat menjadikan hasil penelitian ini sebagai informasi dalam mengatasi kenaikan kadar gula darah pada pasien diabetes mellitus tipe 2 .

\section{DAFTAR PUSTAKA}

Damayanti, Santi. 2015. Diabetes Mellitus dan Penatalaksanaan Keperawatan. Nuha Medika, Yogyakarta

DinkesSUMUT,2009.DataPenelitian: $\underline{\text { http:/ }}$ /rsupadammalik.blogspot.co.id/2013/06/dat a-penelitian-diabetes-mellitus.html, di akses tanggal 15Desember 2018 
Guyton, A.C \& Hall, J.E. (2008). Buku Ajar

Fisiologi Kedokteran. Edisi. 11. Jakarta : EGC

Kusuma, Hardhi dan Amin Huda

Nurarif.2015. Asuhan Keperawatan

NANDA NIC-NOC. Salemba Medika

Setyohadi dan Kushariyadi. 2011. Terapi Modalitas pada Klien Psikogeriatrik.

Salemba Medika, Jakarta

Sudoyo, A.W., Setiyohadi,B., Alwi, I., \& Setiati, S (2006). Buku Ajar Ilmu Penyakit Dalam. (edisi 3). Jakarta: Pusat Penerbit Departeman Penyakit Dalam FKUI

Wild et al., 2018. Report of the Expert Committee on the Diagnosis and Classification of Diabetes Mellitus. Diabetes Care: http://www.diabetes mellitus.com/2018, di akses tanggal 25 November 2018 